\title{
MYTHIC DISPLACEMENT IN NIGERIAN NARRATIVES: AN INTRODUCTION
}

Ignatius Chukwumah

Federal University, Wukari, Nigeria

\begin{abstract}
Five decades of resorting to humanistic critical procedures have bequeathed to the Nigerian critical practice the legacy of examining and discovering in Nigerian and African narratives the historical and social concepts of the time and times they are presumed to posit. These concepts include colonialism, corruption, war, political instability, and culture conflict. These procedures are undertaken without due regard to seeing the whole of the literary tradition as a stream out of which narratives emerge. This article, therefore, by way of introduction, seeks to retrieve Nigerian narratives from "every author" and humanistic critical approach by placing them in a realm where a holistic method such as Frye's could be applied. Here, the traverses of the structure of mythical imagery such as the mythos of crime and punishment as embodied in these narratives and how this structure was displaced/shrouded from Frye's first mimetic mode to the last, via the concept of mythic displacement, will be analysed.
\end{abstract}

Keywords: mythic displacement, mythos, Nigerian literature, Northrop Frye, Wole Soyinka. 


\section{Introduction}

Half a century of criticisms of Nigerian and African narratives reveals critics' inclination for engaging in critical methods that verify what narratives posit against historical data. By this I mean critics seek historically determinate cultural data with which to make sense of narratives. In Nigeria, implicitly or explicitly, this has been the predominant critical position, since the emergence of Things Fall Apart (Attwell, 1984; Erritouni, 2010; Hawley, 2008; Ogungbesan, 1979; Okuyade, 2008; Omelsky, 2011; \& Orabueze, 2010). Even when mythic criticisms are undertaken in relation to these narratives, not much is done to extend beyond the sphere of influence of the above theoretical stance. The consequence is that mythic displacement, the archaic structures of imagery of mythic dimension appropriated by realist narratives, for instance, the mythos of crime and punishment, amongst others, and how they are displaced in Nigerian narratives across a tier of five modes, is largely ignored. This lacuna leaves much for this article to zero into.

\section{Mythic Displacement}

What actually is mythic displacement? For an answer, we turn to literature and its inherent properties, a major one being the acquisition of limited structural patterns, mythoi, from earlier works, thanks to inherited conventions and genres (Frye, Words). Analogically, concepts similar to "mythic displacement" abound 
in Frye's thought. One is the metaphor of the drunken boat and demonic modulations, otherwise known as "the deliberate reversal of the customary moral associations of archetypes" ("drunken" 209; Anatomy 156). The structure of civilization, he says, is like a troubled sea upon which is an ark, a catchall of values and beliefs steered by the ruling class ("drunken"). Below the sea is a dark subhuman power that is looming, recognized by Schopenhauer as the world as will; Freud as id, and Kierkegaard as dread. Both ark and sea images and the symmetrical structure of civilization, Frye argues, duly describe how mythological schemes facilitate in poets the ability to represent man-oriented revolutionary approach to society ("drunken"). In consequence, Atlantis, a mythical place, far beyond reality, (or beneath the sea) becomes an Ararat, a real place to be pointed to. Many Atlantises make up the mythic world which significantly depends on the poet's view of himself, where he is heading from, and his destiny, where he is heading to. Both views are stimulated by his hopes, and fears and it is from this world of myth that literature descends.

The descent is accomplished through a systematic tier of five literary modes to which mythoi can be reduced: the mythic, romantic, high mimetic, low mimetic and ironic modes (Frye, Anatomy). In detailing these modes with regard to Nigerian narratives, one can place the Yoruba collection of myths-John Wyndham's translation of Myths of Ife (1921)-in the first mode, where the central character is a god and superior to other characters and their environment in 
kind. Other myths of the pre-literate segment of Nigeria's literary tradition are identified here. Again, if, in an another instance, the central figure in a work is "superior in degree to other men and to his environment, the hero is the typical hero of romance, whose actions are marvelous but who is himself identified as a human being" (Frye, Anatomy 33). In this hero's world, the commonplace laws of nature are somewhat made to hang while he exhibits great "courage and endurance, unnatural to us... and enchanted weapons, talking animals, terrifying ogres and witches, and talismans of miraculous power violate no rule of probability [...]. Here we have moved from myth, properly so called, into legend, folktale, märchen" and other related subgenres (Frye, Anatomy 33). Some Nigerian examples include the Ozidi Saga (1977) legend as translated by J. P. Clark, The Bayajidda of the Hausa, "The Fulani Creation Story", Fagunwa's The Forest of a Thousand Daemons (1938), Amos Tutuola's The Palmwine Drinkard (1952), and counting.

A criterion of the third category is that, if the central character is "superior in degree to other men but not to his natural environment, the hero is a leader" (Frye, Anatomy 33-34). He possesses "authority, passions, and powers of expression far greater than ours, but what he does is subject both to social criticism and to the order of nature" (Frye, Anatomy 34). This high mimetic mode is where most epics and tragedies are found such as Chinua Achebe's No Longer at Ease (1961), Arrow of God (1964), Things Fall Apart (1958); Soyinka's Death and the King's Horseman (1975); and Ahmed Parker Yerima's Sultan Atahiru, Ameh Oboni the Great, and The Trials of Oba Ovonramwen. 
It should be noted that a slim bound separates legends and the works that belong to this high mimetic mode.

The fourth mode, the low mimetic one, is where the central character is neither greater than his environment nor than other men. Frye asserts, "the hero is one of us: we respond to a sense of his common humanity, and demand from the poet the same canons of probability that we find in our own experience" (Anatomy 33-34). We locate the hero of most comedies and other realistic works of the Nigerian realist tradition here. Also, we have Pita Nwana's Omenuko (1933), D.N. Achara's Ala Bingo (1937), Abubakar Imam's Ruwa Bagaja (Water of Cure) (1934), Nwapa's Idu (1971), Efuru (1966), One is Enough (1981), Sefi Atta's Everything Good Will Come (2006) Soyinka's The Play of Giants (1984), The Jero Plays (1973), and The Lion and the Jewel (1964). In the fifth mode, Frye stipulates that if the hero is "inferior in power or intelligence to ourselves, so that we have the sense of looking down on a scene of bondage, frustration, or absurdity, the hero belongs to the ironic mode" (Frye, Anatomy 34).

Through the above five modes, the structure of a myth, mythos, as articulated by a central character (Frye, Anatomy; Fables), travels from the very first point of clarity and distinction, where it is borne by a god, to the last point of inapparentness and indistinction, where it is evinced by a human being of the least degree, owing to the acquisition of realistic devices. The part played by the realistic devices in shrouding and displacing this structure is aided by convention and genre as it is handed over from one generation of artists to the other (Words). The structure repeatedly dons the façade of human 
characters, operates in lifelike settings, and puts up plausible actions, in contrast to the mythic mode, where it first surfaces.

Though Wole Soyinka's eminent theoretic work, Myth, Literature and the African World (1976), is historically-and cosmologicallyoriented, it is a notable contribution to the study of African mythology. He asserts that "Man exists, however, in a comprehensible world of myth" and proceeds to mass rituals, symbols, and archetypes with myths, leading to one huge skein of Yoruba world (Soyinka, Myth xii). Myth, the sort obtainable in Frye's first mode, is a "primal reality", but not "fantasy", even with the elements of transformation generously abounding (Anatomy 33). African gods, preeminent ones being Ogun and Obatala, are his focus. Obatala bears the "aesthetic of the saint" in suffering, patience, and in embodying Jobic experiences. But unlike Job, he has a weakness for drink (Soyinka, Myth 15). Opposing him in nature is Ogun, "the master craftsman and artist, farmer and warrior, essence of destruction and creativity, a recluse and a gregarious imbiber, a reluctant leader of men and deities" (Soyinka, Myth 27). He "harnessed the resources of science to hack a passage through primordial chaos for the gods reunion with man" (Soyinka, Myth 27). Ogun, the Yoruba god of iron, but not the Greek's Ares, to date still worshipped as a deity, represents or symbolises "the creative destructive principle" (Soyinka, Myth 28), who, when he had become confused about who friend or foe is, "turned on his men and slaughtered them" (Soyinka, Myth 29). Noted for intransigence, Ogun is as inflexible and unyielding as his father, Odudúwa, a major character trait that seems to replicate 
itself in the heroes of Frye's second and third mimetic modes in the Nigerian tradition, accounting for the tragic texture of those narratives where this quality, in form of an image, is found in heroes. In these, I conjecture that Soyinka seems to lump together the literary, cosmological, ritualistic, symbolic, and the structural into one piece of dense theoretic work. This influenced Obou's reading of Wole Soyinka's The Interpreters when he declares that the novel's characters act as agents of the Yoruba mythological gods where their actions are those of two agents and two worlds in one. The mythological deities acting through the characters' attributes, he affirms, affect their imagination, liberate and limit them in whatever they do. This argument, through mythic-sociological criticism, is similar to Roy and Kirpal's who said the characters' beings consist of the self and personality of the Yoruba deities, a combination that serves as contexts for their behaviours (519-27).

But to untie and closely isolate these strands, especially with respect to Nigerian narratives, I find Frye irresistibly useful because he answers the following questions: what structure does the Ogun myth in relation to crime and punishment, for instance, have? How has it been absorbed in modern Nigerian narratives? What identifiable stages are there for the critic to traceably understand this structure as being present in a realistic work? So, as this article focuses on the mythos of crime and punishment, I reason that Frye supplies us through his theory of modes the substance to fill up any missing link. 
All over the world, mythoi travel with the stories that bear them, through all barriers of language and culture interchanging their motifs and themes with other stories (Levi-Strauss 210). Their literary life is at first nomadic, and only later, "often not until the rise of writing, do they become absorbed into the general body of literature" (Frye, Myth 5). The similarity of themes and, hence, mythoi, or structures is a most considerable consequence of this migration of patterns which Frye articulates as "mythological diffusion" (Myth 5). The critic who reads literature, therefore, has an onerous responsibility of making out those archaic mythical patterns that inhere in it, and this is what we shall make of The Interpreters. When an apprehended total structure is "frozen" into a unit (Myth 11), as Frye puts it, a certain pattern is recognisable enough to be given a name, say that of crime and punishment.

Some principles engender, govern and sustain the displacement of mythical patterns from myths to literature and narratives. They are those of analogy and identity. Here, the historical description of displacement, the first merges with the second as two phases of the same account. Also, at this level, metaphor and mythos intersect, in that, while analogy makes a simile-like misleading form, identity, beginning from "momentary deity" (Cassirer 33), tries to align images, metaphorically and mistakenly, to natural elements at the primitive stage of literature (Frye, Fables 35). Additionally, Frye asserts that "Of all images in literature, the most important are characters, the personalities that do most to mediate between the author and his public" (Words 71). 
The consequences of these two principles are as follows. At first, these principles begin with myth, the structure of which, as literary history progresses, other literary narratives have had recourse to the more the work entrenches itself in the tradition, complicating itself with the garb of plausibility via the adoption of poetic images "from actual social conditions of life" (Anatomy 154). It also assimilates some other techniques dictated to it by the conventions of the time. These mythic structures and patterns which have come down to us in narratives and literature are what this article, taking its bearing from The Interpreters and narrowing its focus on the mythos of crime and punishment, aims to investigate.

\section{Analysis}

Before proceeding to cite examples from The Interpreters and a few Nigerian narratives, some instances relating to the displacement of myth as illustrated by Frye are worth mentioning:

In a myth we can have a sun-god or a tree-god; in a romance we may have a person who is significantly associated with the sun or trees. In more realistic modes the association becomes less significant and more a matter of incidental, even coincidental or accidental, imagery. In the dragon-killing legend of the St. George and Perseus family, of which more hereafter, a country under an old feeble king is terrorized by a dragon who eventually demands the king's daughter, but is slain by the hero. This seems to be a romantic analogy (perhaps also, in this case, a descendant) of a myth of a waste land restored to life by a fertility god. In the myth, then, the dragon and the old king would be identified. We 
can in fact concentrate the myth still further into an Oedipus fantasy in which the hero is not the old king's son-in-law but his son, and the rescued damsel the hero's mother. If the story were a private dream such identifications would be made as a matter of course. But to make it plausible, symmetrical, and morally acceptable story a good deal of displacement is necessary, and it is only after a comparative study of the story type has been made that the metaphorical structure within it begins to emerge. [...] Or, again, we have, in myth, the story of Proserpine, who disappears into the underworld for six months of every year. The pure myth is clearly one of death and revival; the story as we have is slightly displaced, but the mythical pattern is easy to see. The same structural element often recurs in Shakespearean comedy, where it has to be adapted to a roughly high mimetic level of credibility. Hero in Much Ado is dead enough to have a funeral song, and plausible explanations are postponed until after the end of the play. Imogen in Cymbeline has an assumed name and an empty grave, but she too gets some funeral obsequies. But the story of Hermione and Perdita is so close to the Demeter and Proserpine myth that hardly any serious pretence of plausible explanations is made. Hermione, after her disappearance, returns once as a ghost in a dream, and her coming to life from a statue, a displacement of the Pygmalion myth, is said to require an awakening of faith, even though, on one level of plausibility, she has not been a statue at all, and nothing has taken place except a harmless deception (Frye, Anatomy 137,138).

A major feature of the mythos of crime and punishment is that its world is demonic, which largely personifies "the vast menacing stupid powers of nature" or humans acting as its agents (Frye, Anatomy 147). It is a world of nightmares, scapegoat, bondage, pain, and confusionin fact, a world "closely linked with an existential hell" and suffering, which desire utterly rejects (Frye, Anatomy 147). This mythos transcends its earliest points of manifestations in ancient Nigerian 
mythical texts to appear traceably in Wole Soyinka's The Interpreters and other realistic narratives. In these narratives, the mythos not only problematises itself, it also implicates the pharmakos mythos. This is because from the suffering of characters, one wonders what their sins or crimes are. In cases where crime is committed, one is eager to find out what degree of punishment undergone by a character would be justifiably commensurate to his crime. Or in instances where the offence is insignificant or greatly exceeds the offence, one is amazed as to why a character should suffer much for little or nothing. As regards the structure of crime and punishment, suffering is at the individual level, but at the level of the figure of the pharmakos, the tragic suffering undergone is on behalf of a group or circle of persons larger than the individual, provoking the purgation of such emotions of pity and fear.

In The Interpreters, for instance, where the displaced structure of crime and punishment can be outlined, Golder's retribution for provoking his father's suicide is exile and wandering, even though a greater part of his punishment occurs in the psychological sphere. Other characters and he are punished, in different ways and degrees, for their actions and inaction. Egbo also does not see his deriving immoral pleasure from Bandele's student as an offence until he is told that Simi is on her way to see him in Bandele's apartment in The Interpreters. Once more, Sagoe sees nothing wrong in giving some fifty pounds bribe to Chief Winsala and Sir Derinola, alias The Morgue, until the end of the textual space. The bribe Sagoe gives can, in due course, be related to the freedom he lacks to do his job. The 
Independent Viewpoint editor, Mr. Nwabuzor, tells him this if we read closely enough. Mr. Ayo Faseyi, the intelligent laboratory technician, is another offender. It may not be perceptible to a casual gloss that his craze for Western values and forcing his wife to abide by them is an offence. He heads towards the grievous consequences of a failed marriage, such as emotional trauma and imminent separation or divorce. Noah, who absconds from Lazarus and his intention of enlisting him in religious ministerial services in his church, is punished. He wants to be free from the limitations of ministerial obligations Lazarus has bequeathed to him to follow the dictates of his mind.

There is no apparent punishment for this action of abscondment, but there exists a subterranean relationship between his accidental death in the hands of Joe Golder after he jumps over a flight of eight stairs. On his part, Golder's punishment for provoking his father to commit suicide after spitting on his skin to his father's face is his wandering. Prior to his impoliteness, he was not an exile, wanderer, and a quester. His enigma rests on the consequences of that singular misdeed. He is one character, in The Interpreters, that is most dense, most inclined to yielding meaning endlessly when subjected to examination. They are punished in different degrees for what they, somehow unknowingly, have done.

Prof Oguazor fathers a child in The Interpreters by his housemaid and whisks the child away from public view to faraway United States. His is an instance of wrestling with the pain of shame-punishment 
for his moral failure. What he tries to avoid, a sudden fall from his high opinions of the society, suddenly yields without his doing and bursts for public view. He is punished all the same for it later becomes an open-secret. Only he is not aware that others are privy to it-a situation that resembles one living in a transparent glass house and feigning secrecy when his daily routines are before public scrutiny. Regardless of this, he does not fail to seize the opportunity to lash the undergraduates in the university where he works accusing them of being "merally corrupt" and then, say, at general public, that "the whole country is senk in meral turpitude" (Soyinka, Interpreters 251). Feigning devotion for his work place, he says "The college cannot afford to herve its name dragged down by the meral turpitude of irresponsible young men. The younger generation is too merally corrupt" (Soyinka, Interpreters 252). He does not seem to include his generation, for which he is a prime example.

Egbo can be seen to be punished by some strange haunting which can be traced to his having rejected the Osa stool in The Interpreters. The dead, he claims, should have no faces, by which he means history or past acts should never haunt the present decisions and moods. But this fails. For example, he seems satisfied not taking over the stool of Osa Kingdom which is his right through his maternal lineage. But by adding "I can't complain" (Soyinka, Interpreters 5), it becomes evident that his decision left much to be desired. It takes only the rain washing into his beer to trigger the latent haunts, in his memory, of a rejected valuable prize underlining his statement: 
"memories do not hold me" (Soyinka, Interpreters 7). Egbo pours out his glass of beer into the rain, saying in the same vein that "I don't need his pity. Someone tell God not to weep in my beer" (Soyinka, Interpreters 5). One hears him react, through the narrator, thus: "a slow anger built in him, panic and retraction from the elaborate pit" (Soyinka, Interpreters 10). He is also "drawn to it as a dream of isolation, smelling its archaic menace and the violent undertows, unable to deny its dark vitality" (Soyinka, Interpreters 10). This state of in-between opinions is part of the foundation of his pain as angstmiserable mood in respect of which he tells the sky: "Didn't beg you to join in celebrating any depression" (Soyinka, Interpreters 104). Fighting this haunt suggests a lame attempt to fend off the ravaging punishment for the unwise decision made in the past. The past as a burden of memory moderates and directs Lazarus' interpretation of how Noah dies, too.

Through the above, heroes or characters suffer in consequence of some offence or sin. Instances abound in this mythos where the crime committed is hardly known. In this occasion, the sufferer or the punished inaugurates the figure of the pharmakos who is found in a world held together by a "molecular tension of egos" (Frye, Anatomy 147). His situation is that of Job in that he is "neither innocent nor guilty" for his suffering (Anatomy 41), implying that he stands on the fence, where guilt and innocence can equally be located in him. A character could be said to be wholly innocent because he chances to belong to a group, either by biological involuntariness and nature 
over which he has no control, or by virtue of education or lack of it, which prepares the ground for what now confronts him. Yet, as is inferable from Frye, he is guilty because he is a "member of a guilty society, or living in a world where such injustices are an inescapable part of existence" (Anatomy 41), and he has dismissible flaws which attract an avalanche of consequences in excess of those flaws (Anatomy 41). Of all the characters in The Interpreters, Sekoni is the most qualified figure of a pharmakos due to society's utter rejection of his pet project and his person. These impact consequently on the overall tragic texture of his life and leading to his death. The classic image of the pharmakos is found in the Judaeo-Christian's scriptures' Jesus, Job, the Jew, and, secularly, the artist (Anatomy 39). The artist, mentioned here, reminds us of Kola and Sekoni in The Interpreters.

So far, Egbo, Sekoni, Prof Oguazor, Sagoe, Golder, Sir Derin and others in The Interpreters prop the imagery that form the displaced structure or formula of crime and punishment, although only Sekoni, sustains pathos. The mythos of crime and punishment in The Interpreters is mainly sedimentary in its displaced capacities requiring interpretation and uncovering as ordinarily unrelated items are seen to be related and relate. The characters are humans of our experience and we recognise them through their setting, actions, names, idiosyncracies, and all other character traits found in humans. On the platform of the above, one can read these texts against others within the same genre as narrative and within the convention of tragedy. 
The mythos of crime and punishment has, overtime, traversed space and time through conventions and genres within Nigerian literary tradition and beyond, to appear in The Interpreters. In the first literary mode, myth, in which the hero is superior in kind to the environment and other characters, an example of which, outside Nigeria's tradition, is the Sisyphus myth, we see how he bears an analogous mythos in his being condemned to roll up a bolder that returns as soon as it reaches the peak of the mountain in Tartarus. Nevertheless, what occasion the punishment of characters in The Interpreters and most Nigerian narratives and that of Sisyphus differ. Sisyphus offends the King of the gods, a latter image which Golder's father fits, by telling on him when he abducts the maid, Aegina; hence, the punishment meted to him is inescapable. On the other hand, in The Interpreters, Egbo offends the ethics of his society of humans above which he could not live, as he just must live under these ethics and be gagged.

Within the Nigerian tradition, a most important work where this mythos of crime and punishment is recovered, in its undisplaced form, is Wyndham's Myths of Ife's segment, "The War of the Gods". Odudúwa subtly strips Orisha of the bag of "knowledge of the ways of mysteries and hidden things" and craft and skilfulness that Great Arámfè gave to him as the firstborn to teach and empower man (Wyndham n.p.). Where subtlety is instrumental in getting the bag from the rightful owner, mild supplication fails to restore it. The resultant strife, plunder and war that engulf the then "primal" world 
of gods and man-Ife, in spite of Ogun's intervention, is captured by the narrator in these words: "so that day the first of wars began/ In Ife and the Forest. Such was the fall/ Of Gods from paths divine, and such for men/The woe that Odudúwa's theft prepared" (Wyndham n.p.). First, it is strife, lack of peace and progress that Ife suffers-all of Ife; later, it is death that Odudúwa, bearing the bag away, punishes himself with. His death is a sort of suicide of the first mimetic mode, this transformation to a stone and sinking "beneath the soil" in his ruse to get back to Arámfè to live the ideal life (Wyndham n.p.).

The individual, Odudúwa, as well as the community, Ife, are punished not only with strife, but also with, through the disappearance of Odudúwa, the loss of "voiceless lore and arts which found no teacher" (Wyndham n.p.). The ultimate suffering, punishment, is perpetual ignorance not for the offence of men alone, but also of the gods who sinned before man ever came to be. While Sekoni's suffering, in The Interpreters, brings about the purgation of the emotions of pity and arousing of pathos, the suffering of gods and men is not so. Rather, theirs is akin to the kind found in melodrama, which is not really worked out leading to climax where recognition and the reversal of the situation set in at the same time upon the sufferer.

The identification of the mythos of crime and punishment in this work, Myths of Ife, is easy. It belongs to the mode where all the major characters: Orisha, Ogun, Odudúwa, Arámfè, Olokun, Forest, and so on are gods in their respective rights. They privilege and support an 
ethnic group's idiom in addition to bearing historical and religious significances. Incidentally, it is here that literature is presumed to possess the greatest import to man, like is found, outside the Nigerian literary tradition, in Homer's The Odyssey, Aeschylus's Agamemnon, The Eumenides, and Prometheus Bound. Where they are not fully gods, they descend directly from the lineage of gods, as Oedipus is descended from Cadmus, the founder of Thebes and Achilles, given birth to by both Thetis, the sea nymph and Peleus, king of the Myrmidons of Thessaly. The mythos in this mode is later to shed off properties of pure indisplacement as it enters into the second mimetic mode through the aid of the convention of tragedy. Humans exist in the background in the Myths of Ife; they are only heard about in passing, but never seen in action. This is not surprising because this mode does not tolerate them, unlike in the others where recognisable humans are found as in The Interpreters.

The positing of the mythos of crime and punishment is narrowed out a little in the second mode where folktales, romance, legends, märchen, the tortoise tales and others are found. In this mode also, this mythos is slightly displaced as we recognise life-like humans. In the Nigerian literary tradition, Kako and others could not return from their quest in The Forest of a Thousand Daemons due to conceit. Of the seven that undertake the journey to Mount Langbodo, only Imodoye, Olohun-iyo and Akara-Ogun return safely home. Death is their punishment for "simple conceit" (Fagunwa 138). Their success went to their head and they throw caution to the winds, incurring 
the spirits' punishment. Such one-on-one correlation of cause and effect traced out in Fagunwa does not appear self-evidently in a realistic work as The Interpreters, but it is there, despite everything, to be interpreted. Akara-Ogun continues that "If a man overreaches himself, he crashes to the ground"; they "were smitten with this arrogance, they listened no longer to the suggestions of others... everyone behaved as he wished" (Fagunwa 138). But he soon attributes these deaths that befall his colleagues to the handiwork of a super-being: "according to the habit of our Creator, He employs two methods to punish the sinner, either He punishes him immediately or He notes down his sins in the record book" (Fagunwa 138).

As for his colleagues, this super-being resorts to the first option, for "instant was their punishment" (Fagunwa 138), as he acts as a dispenser of punishment for the sinner that errs. But what makes him to resort to the first drastic option and not the latter is not clear. What is clear is that he does not dispense punishment except one has sinned. Perhaps, this further explains why a human agent is involved to mete out punishment in Hamlet because the same super-being adopts the latter approach when he ought to act in consonance with the above manner as in Akara-Ogun's colleagues. The domestic or regal tragedy that takes place in Hamlet, nevertheless, is punishment for the crime of covetousness, human act of vice, and not conceit.

Besides The Forest of a Thousand Daemons, "Why Men Die", a folktale, two brothers: Akpu and Nku, clearly inaugurates the mythos of crime and punishment by reason of the elder, Akpu's 
susceptibility to the old magical fairy's hypnosis, a consequence of his uncircumspective eating of her charmed food. The younger brother, $\mathrm{Nku}$, is judicious by not eating. We notice that while they are noticeably human, under some spell before which they are powerless, the old woman is not a human person, for by virtue of her acquired nature, she is severally referred to as "a wicked fairy" that lives in "Fairyland" (Okereke 30). So the mythos of crime and punishment has undergone partial displacement. The elder brother's eating of the old woman's food is enough to qualify as crime which she capitalises on to deal with him.

A similarly partially displaced mythos is found in "Obidiya and Mgbechi: The Story of the King's Two Wives", "The Fisherman and his Wife", "The Cunning Tortoise", "How Rabbit Was Punished", "Omelumma and Omelukpagham", "The Proud Girl and the Devil", "Efik Myth", "The Hippopotamus and the Tortoise", "Why the Sky is Far Above the Earth", and "How Tortoise Got His Revenge on Lizard". Mgbechi and Obidiya are wives to a wealthy king but have no children. Whereas the tale is almost all too human-oriented offering a strident influence of verisimilitude as is found in The Interpreters and evincing huge displacement, the presence of an old lonely fairy with supernatural powers of giving rewards and punishments to supplicants who meet and do not meet the condition of good character heaves it farther away from realism into the category of märchen. This is the second mode.

In tales of the second mode, the mythos of crime and punishment is clear and almost always easy to point out. A case in 
point is Nku, whose reservation and discretion is responsible for his escape from the wicked fairy's charm of death. Similarly, discretion results in Mgbechi's kindness, humility, and truthfulness, which are requirements for passing the old child-giving fairy's test as they earn her children. But it is not going to be that easy for someone else. Obidiya, her mate, with opposite qualities, urged by Mgbechi's success, assays getting children, too, but meets with failure, disgrace and eventual dismissal from her matrimonial home.

The entire community of the poor fisherman in "The Fisherman and his Wife" is punished with a plague when the king takes his wife, the beautiful mermaid who chooses to be his and by whom he is made rich. One of the counsellors said: "I think we are being punished because you took another man's wife for yourself" (Adams 11). As other animals punish Rabbit with a depressing joke and jeers for his notoriety for being a busy-body and for eavesdropping in "How Rabbit Was Punished", so does a magic antelope punishes the hunter in "The Hunter and the Antelope" for his greed. Three times, he asks whatever he wishes: a very big farm, five hundred bags of gold, and to be one of the chiefs of the town, and these three times, he is granted them. But, at the fourth, when he comes with the usual threat to kill it unless he is made the king of the entire town, he is told: "You are a foolish, greedy and wicked man [...]. You'll never be king! [...] Nobody can kill me; I am the spirit of the forest. And I will punish you for your greed. From now on, you will be poorer than you were" (2006: 50). Omelumma and Omelukpagham are enslaved, which is their punishment for disobeying their parents when they 
neglect taking precautions that would have saved them in the days of slave raids. In these tales, the mythos of crime and punishment is done by an individual character and the same individual suffers the consequences.

In these instances, superhuman characters, for whom the laws of nature are not meant and unto whom they do not pertain, are involved, thereby supplying many characters that have power over their contemporaries and their environments in degrees to posit this mythos. They contrast with most characters who are on the level of our experience as found in The Interpreters. While, in The Interpreters, the characters' punishment is for offences that are somewhat indistinct inasmuch as they are displaced, in the above tales, because they are almost not displaced, they are distinct. Whereas those who suffer punishment in the above tales are obviously humans, what enhance the plot are not subject to the law of nature and so are far removed from reality.

Let us take "The Proud Girl and the Devil" as another case. She suffers for being conceited because of her beauty. This mythos obtains in the Yoruba's "The Leopard Man", the only difference is that in the present case, the strange suitor who eventually finds favour in the hands of the heady maid is a devil and not a leopardturned-man. In "The Proud Girl and the Devil", while Adamma is rescued, her type in the other tale is not so lucky; she goes through her ordeal until she finally dies. However, can it really be arrived at that the mythos of crime and punishment in this tale is undisplaced 
and, therefore, lacking, in totality, the technical details of realism and plausibility? The answer is "no" and "yes". The "far country" where the devils live is not the domain of humans. Nonetheless, it is near enough for the notoriety of Adamma to get to. Hence, with all their abnormal natures, once the devil-suitor is chosen, he sets about to appear in bodily form human enough to be believed, liked, and loved by Adamma by borrowing complementary body organs from humans/devils.

This make-believe episode, which the realistic literary technique also resorts to, is shed off at the time he also returns the borrowed body parts to those who lent him. This is the point of no return for Adamma. This segment of the tale pushes it far beyond verisimilitude into fantasy and the unreal. The other segment of the tale, where Adamma's parents' counsel her, is in tension with the fantastic segment. It finally drags it beyond the high mimetic mode to the low mimetic category as realism appears to reach its optimum. Adamma is human but the devil is not. Nevertheless, what occasions the punishment of characters in The Interpreters and that of Sisyphus or those of the characters analysed above obtaining in the first mode, differs.

If one comes down lower to the high mimetic category, the third mode within the same genre of narrative and convention of tragedy where the major character is a leader or is a member of a leading caucus and has authority, what is noticed is a mythos losing its first time intelligibility and apparentness. It requires some labour and the 
upturning of some clods for meaning to be recuperated having been fleshed up by plausible adaptations.

In Chinua Achebe's Things Fall Apart, Okonkwo stands out as the sole sufferer drawing together pathos, purging pity and fear, and pushing forth the mythos of crime and punishment disguisedly, before the rest of Umuofia does doing despite to Uchendu's attempt at universalizing pain in his refrain: "To whom is it well?" (95). It is here too that he as a pharmakos or random victim begins to emerge, due to the indistinctness of offences and crimes he is presumed to have committed. The crimes have the potential of leading, interpretively, to antimonies.

There is really nothing suggesting supernatural aid in the life of Okonkwo in Things Fall Apart. The remark that his palm kernels were cracked for him by some benevolent spirits is only valid in the sphere of gossip and not the real. There is no purposive assistance or impact from the superhuman, though it hovers, it is not perceived. So with this situation, Things Fall Apart is retained in the arena of a heroic tale where the mythos of crime and punishment, somewhat discernible in and attributable to his actions as volitional being, makes Okonkwo take a seat amongst such characters as Sagoe, Egbo, Egbo, Eugene, and Ezeulu, to list just four. Farther away, the shadows of Prometheus, Sundiata, Odysseus and many more are behind him. Ezeulu, in Chinua Achebe's Arrow of God, lurks behind the figure that Okonkwo represents. Being a spiritual leader before the intervention of the white man and, after it, a political head or with 
the prospect of becoming such, as Winterbottom aptly interprets his titular appendage, the Priest-king, he puts himself in the same position as God the Creator by not telling the community to proceed to celebrate the feasts of the Pumpkin Leaves and the New Yams when cosmos has designated otherwise. The mythos of crime and punishment displaces itself in the work through his figure as he is humbled and the reverence given to Ulu torn to shreds. But then, it is not this simple, this offence of his.

Other factors, not emanating from him perse, are also responsible for his fall. Ogbuefi Nwaka's insolence is one; his being seen as the friend of the white man when he never meant or craved to be so, is another. He only happens to have found favour after he gave a true testimony in the land case between his clan and another. Many other factors abound.

All of these are valid reasons for his action, a situation that makes this said cause of his punishment to be unclear. This inclarity indicates that the mythos has undergone displacement between the two previous modes and this. It also shows that the realistic technique has done some harm to the pure mythos we met at the mythic and folkloric levels, in the same way it is shrouded in The Interpreters, No Longer at Ease, and Anthills of the Savannah. While Okonkwo and Ezeulu are leaders by traditional standards, both contextualised in the cultural norms of the Igbo group, Obi Okonkwo and Sam of the last two works, are leaders by the standards of a modern country: the first, as an educated modern 
African and, the other, a General in a modern army. With the last being a 'general', he sets himself apart from the crude military might that Umuofia wielded in Okonkwo's days.

Also included in this mode are Chimamanda Adichie's Purple Hibiscus (2003), Half of a Yellow Sun (2007), and other works. A historically validated violence technically serves as the atmosphere of both works. Nonetheless, they are of different kinds: coup, in the case of Purple Hibiscus and, war, in Half of a Yellow Sun. Both are, in addition, purely literary historical praxis in both works. In the case of Purple Hibiscus, the administrations of Generals Ibrahim Babangida and Sani Abacha are made to be contiguous and sequential omitting, historically, the regime of Ernest Shonekan.

A similar instance, in reverse, is presented sequentially in the assassination of Kudirat Abiola and Dele Giwa under the regime of Abacha in Habila's Waiting for an Angel, transposing about ten years' space of history. Disappointing to any factual probe but advantageous to enhancing the technique of plausibility in a work of this particular mode, where, though, none of the characters is a supreme leader, but by virtue of their education, all are leaders positing the mythos of crime and punishment as an undercurrent structure, characters worthy of heroic ascriptions come into view. They include Odenigbo, Olanna, Richard, Miss Adebayo, and even the northern Prince, Mohammed in Half of a Yellow Sun and Eugene, a Catholic patriarch, newspaper proprietor and manufacturer and Ade Coker, his Editor, in Purple Hibiscus. In Purple Hibiscus, Eugene is "punished" for his 
harshness as he is poisoned by the loved ones he weeps and cares for. Like Okonkwo who is placed between the dawn of fading old ways and the advent of the new, Eugene is placed in the context of the established new ways which Okonkwo has rejected. Nonetheless, both are one because they are analogous figures in the handling and ruling of their families. In a way, both histories are divergent but serve identical purposes-dressing the work in verisimilitude as Sekoni, Sagoe, and others do in The Interpreters. Despite Kambili's youngness, she echoes Sekoni's and other characters' moodiness in The Interpreters. This mythos, propped by all of them, is hugely displaced in terms of contemporary settings instead of the fantastic sort; human actions in place of gods'; lifelike human names as substitutes for metaphoric and ritual-emanating names, and so on.

By the time the hero of the fourth mimetic category, who is neither superior to other men nor his environment, enunciates the mythos of crime and punishment, readers find they can respond to him with a sense of commonality. Only few undisplaced elements are however still retained. The hero is inarticulate and his inarticulateness gives the work the structure of pathos where only the emotion of pity is aroused to the point of tears but not fear. In this low mimetic mode, the mythos of crime and punishment is recoverable from Gabriel Okara's The Voice, Okpewho's The Victims, Tides, The Last Duty, Iyayi's Violence, Jude Dibia's Unbridled, Walking with Shadows, and Soyinka's Aké: The Years of Childhood. Even in The Interpreters, he suffers, arousing the emotion of pity for taking his stand against 
an iniquitous convention. This is his crime. This stand is present in the works listed above onto which their tragic element is attached. To Ikolo in The Voice, he would not stop asking for who has found it; for Tonwe and Piriye in Tides, they would not, in spite of being sidelined and pushed into the far end of life, stand by and see the pillaging of their environment and making it arid through the collusion of the state and the oil companies; and for The Last Duty's Oshevire, the plot of land that rightfully belongs to him must not be yielded to one who bullies him to get it-it would be over his corpse. He is made in the stuff of biblical Naboth.

In Violence, Ogbemudia would not be intimidated by the corrupt nouveau riche of a generation of corrupt Nigerians. Ngozi's sole escape route out of filial sexual harassment and deprivation is to gullibly grasp the prospect of love outside Nigeria's shores and be a British citizen in Unbridled and, in Soyinka's Aké, the orderliness, economy, and peace of the colonialists and native rulers must be shredded by the women of the town through the rejection of the imposition of taxes, despite threats. The stands taken make most of these works, excluding the Unbridled and Aké, to arouse pity and fear which are eventually purged. We also see how the crime or offence committed by one boomerangs as forms of punishment, such as pain, discomfort, and chaos. It is also clear too that this structure has been displaced as certain historical elements have emerged and come up to the surface of the texts, thereby shrouding the mythos from immediate identification. 
The mythos of crime and punishment in these works puts on several garbs in an apparent technical move of disguise, which if we disrobe, would reveal what it really is-the structure that is as bare as it has been in Myths of Ife's Ife-with its gods and humans. In the second mimetic works, we have seen it in "Obidiya and Mgbechi: The Story of the King's Two Wives", "The Fisherman and his Wife", "The Cunning Tortoise", "How Rabbit Was Punished", "The Hunter and the Antelope", "Omelumma and Omelukpagham", "The Proud Girl and the Devil", "Efik Myth", "The Hippopotamus and the Tortoise", "Why the Sky is Far Above the Earth", and "How Tortoise Got His Revenge on Lizard". Such garbs are 'the Nigerian civil war', a term critics have recognized differently by classifying such works positing such contexts as “War Fiction”; 'Britain', 'Nigeria,' 'Babangida,' 'Abacha', 'Niger Delta,' 'crude oil' and other numberless devices of plausibility of historical contexts, human actions, and settings which formed the critical scope of Hawley (2008); Okuyade (2008); Omelsky (2011); \& Orabueze (2010).

When the mythos is spotted in the last mimetic and ironic mode, bearing the traces of characters of the first and second mimetic modes, the indistinctness it acquires in the third mode via donning realistic "dress" or shroud, begins to fade. In such works as Ben Okri's Astonishing the Gods, "In the Shadows of War", a short story segment of the Stars of the New Curfew, pain and chaos are unleashed upon a town as the inhabitants evacuate leaving behind its ghost. In another short story, "Worlds that Flourish", we see such manifestations as 
frustration, horror and torture and we ask: what offence have these characters committed? This is the mode where offence committed is hardly discovered. The Job figure flowers here; it is a world of pain just as we hear the main character of "Worlds that Flourish" being told: "Don't go that way. Find where you can be happy" (Okri 33). This is what he is repeatedly told when he finds himself at crossroads after escaping frustration-an experience that has no alternative. $\mathrm{He}$ seems to rely on what he is told; he has no discretion. This agrees with Frye's description that the hero of this mode is "inferior in power or intelligence to ourselves, so that we have the sense of looking down on a scene of bondage, frustration, or absurdity" (Anatomy 34). Thus, when the reader identifies himself with him by feeling that he could as well have been the one, this identification is not a mere response provoked by art; rather, the reader's assessment has only proceeded from a vantage point of greater liberty.

\section{Conclusion}

So far, an observation of the above displaced mythos of crime and punishment shows its tendency for descending down the five mimetic modes. In its descent, evidences show "the structural principles of a mythology, built up from analogy and identity, become in due course the structural principles of literature" as manifest in The Interpreters, narratives of the Nigerian literary tradition, and beyond (Frye, Fables 33). It has also aided the teasing out of the complex tangle found in 
Soyinka's Myth, Literature and the African World through the prism of Frye's first mimetic modes and the concept of mythic displacement, the traverses of the mythos of crime and punishment, and how it has been displaced in the above narratives. This displacement reveals to us that beyond the copious humanistic criticisms of Nigerian narratives, a structural pattern such as the mythos of crime and punishment, amongst others, can be analysed. It is hoped that this would open a new chapter of critical re-orientation of the Nigerian critical practice and offer a key for rethinking Nigerian narratives.

\section{References}

\section{Primary Sources}

Achebe, C. Things fall apart. Ibadan, NGR: Heinemann, 1958.

Adams, A. "How rabbit was punished". The Cunning Tortoise and Other Stories. Lagos, NGR: Lantern, 2006. 15-20.

Fagunwa, D.O. The Forest of a Thousand Daemons. Lagos, NGR: Thomas Nelson, 1982.

Okereke, O. "Why men die". In P. Bordinat and P. Thomas (Eds.) Revealer of Secrets. Ibadan, NGR: African University Press, 1975. 27-32.

Soyinka, W. The interpreters. London: Fontana, 1972.

Wyndham, J. "The wars of the gods". Myths of Ife. 1 June 2010. Retrieved from http://www.sacred-text.com/afr/ife/index.htm, 2002.

\section{Secondary Sources}

Attwell, D. "The British legacy in Anglophone literary criticism". English in Africa. 11.1 (1984): 79-106.

Awosika, O. Form and Technique in the African Novel. Ibadan, NGR: Sam Bookman, 1997.

Cassirer, E. Language and Myth. New York: Dover, 1946. 
Erritouni, A. "Postcolonial Despotism from a Postmodern Standpoint: Helon Habila's Waiting for an Angel". Research in African Literatures, 44(4), (2010): 144-161.

Frye, N. Anatomy of Criticism: Four Essays. Princeton: Princeton University Press, 1957.

. "The drunken boat: the revolutionary elements in romanticism". The stubborn structure: essays on criticism and society. London: Routledge, 2011. 208-20. . Fables of Identity. New York: Harcourt Brace, 1963. . Myth and Metaphor: Selected Essays 1974-1988. Robert D. Denham (Ed.). Charlotteville, US: University of Virginia Press, 1990. Words with Power. New York: Harcourt Brace, 1990.

Hawley, J. C. "Biafra as heritage and symbol: Adichie, Mbachu, and Iweala". Research in African Literatures 39 (2), (2008): 15-26.

Korang, K. L. Making a post-Eurocentric humanity: tragedy, realism, and Things fall apart. Research in African Literatures, 42(2), (2011): 1-29.

Levi-Strauss, C. Structural Anthropology. New York: Basic Books, 1963.

Morrison, K. "To dare transition": Ogun as a touchstone in Wole Soyinka's The interpreter." Research in African Literatures, 20 (1), (1989): 60-71. "The second self as vision of horror in Wole Soyinka's The interpreters". Black America Literature Forum, 22 (4), (1988): 753-765.

Obou, L. "Myth as substance: capturing the essence of personality in Wole Soyinka's The Interpreters". Editions Universitaires de Côte d'Ivoire (EDUCI), 19, (2008): 39-48.

Ogungbesan, K. "Wole Soyinka and the novelist's responsibility in Africa". In K. Ogungbesan (Ed.), New West African literature (pp. 2-9). London: Heinemann, 1979. 2-9.

Okri, B. "Worlds that flourish". Stars of the new curfew (pp. 13-36). London: Vintage, 1988. 13-36.

Okuyade, O. "Of the versification of pain: Nigerian civil war poetry". African Literature Today, 26, (2008): 128-136. 
Omelsky, M. "Chris Abani and the politics of ambivalence". Research in African Literatures, 42(4), (2011): 84-96.

Orabueze, F. "The prison of Nigerian woman: female complicity in Sefi Atta's Everything Good Will Come”. African Literature Today, 27, (2010): 85-102.

Roy, A., \& Kirpal, V. "Men as archetypes: characterization in Soyinka's novels". Modern Fiction Studies, 37(3), (1991): 519-27. 3 Aug. 2010. Retrieved from https://www.endnotes.com

Soyinka, Wole. The Interpreters. London: Fontana, 1972. . Myth, Literature and the African World. Cambridge, UK: Cambridge University Press, 1976.

(Received in 16/06/2013. Approved in 19/08/2013) 
